\title{
EXPERIMENTAL STUDY OF SILVER NANOFLUID ON FLAT HEAT PIPE THERMAL PERFORMANCE
}

\author{
Yu-Tang Chen \\ Department of Mechanical Engineering, De Lin Institute of Technology, Taipei County, Taiwan, R.O.C., \\ ytang.chen@msa.hinet.net
}

Follow this and additional works at: https://jmstt.ntou.edu.tw/journal

Part of the Engineering Commons

\section{Recommended Citation}

Chen, Yu-Tang (2010) "EXPERIMENTAL STUDY OF SILVER NANOFLUID ON FLAT HEAT PIPE THERMAL

PERFORMANCE," Journal of Marine Science and Technology. Vol. 18: Iss. 5, Article 14.

DOI: $10.51400 / 2709-6998.1925$

Available at: https://jmstt.ntou.edu.tw/journal/vol18/iss5/14

This Research Article is brought to you for free and open access by Journal of Marine Science and Technology. It has been accepted for inclusion in Journal of Marine Science and Technology by an authorized editor of Journal of Marine Science and Technology. 
EXPERIMENTAL STUDY OF SILVER NANOFLUID ON FLAT HEAT PIPE THERMAL PERFORMANCE

\section{Acknowledgements}

This work was supported by National Science Council of Taiwan, Republic of China under contract No. NSC 96-2622- E-237-005-CC3. In addition, the author would like thank Professor Kang Shung-Wen (Department of Mechanical and Electro-Mechanical Engineering of Tamkang University, Taiwan) for his invaluable help and guidance. 


\title{
EXPERIMENTAL STUDY OF SILVER NANOFLUID ON FLAT HEAT PIPE THERMAL PERFORMANCE
}

\author{
Yu-Tang Chen*
}

Key words: flat heat pipe, nano-fluid, nano-particle.

\begin{abstract}
This study utilizes silver nano-fluid filled flat heat pipe. It is aimed at effect of various concentrations on flat heat pipe thermal performance by air-cooling testing equipment. The particles used in these experiments were silver particles $35 \mathrm{~nm}$ in size. The base working fluid was pure-water. Nano-fluids were prepared using a two-step method. In the experiment, the thickness and length of the heat pipe are $3 \mathrm{~mm}$ and $200 \mathrm{~cm}$, respectively. An experimental system was set up to measure the temperature distribution of heat pipes and calculate the thermal resistance by equation $R=\Delta T / Q$. At a same charge volume, the thermal resistance of heat pipe filled nano-fluid was lower than DI water.
\end{abstract}

\section{INTRODUCTION}

With "tera-scale computing" is coming [29], that means the more heat generation will accompany in compact electronic components. The requisite thermal management for a personal computer is most often achieved via heat pipe (HP), heat sink and fans. In general, the flat heat pipes (FHP) are usually used as notebook cooler, due to its favorable thermal characteristics and flexible. In 2000, Wang and Vafai [26, 27] investigated the thermal performance of the FHP, their results showed (1) the wick in the evaporator section provides the largest resistance to the heat transfer process, (2) the heat transfer coefficient strongly affects the time it takes to reach steady state, (3) the experimental results were compared with analytical results and were found to be in very good agreement. Peterson and Wang [25] developed a novel FHP, which utilized the sintered copper screen mesh as mainly wick structure, the experimental results showed the maximum heat transport capacity can reach $112 \mathrm{~W}$ and $123 \mathrm{~W}$, respectively. However, the thermal performance of traditional circular HP is better than FHP. In order to enhance the heat transfer efficiency, an innovation heat transfer fluid called nano-fluid has developed by Argonne National Laboratory [3].

Paper submitted 06/16/09; revised 10/07/09; accepted 10/09/09. Author for correspondence: Yu-Tang Chen (e-mail: ytang.chen@msa.hinet.net).

*Department of Mechanical Engineering, De Lin Institute of Technology, Taipei County, Taiwan, R.O.C.
Numbers of experimental investigations have demonstrated the nano-fluid with higher effective thermal conductivity and critical heat flux [2, 4-7, 11, 12, 18, 22, 24, 30-33]. These are the advantages in application such as heat transfer devices. From 2004 to 2009, nano-fluids were filled in heat pipes [1, $8,9,13,23,35]$, thermosyphon [10, 14, 34], oscillating heat pipes [15-17, 20, 21]. However, the silver nano-fluid filled on FHP thermal performance has never investigated. Therefore, the purpose of present study is to investigate the effect of nanofluid on FHP thermal performance.

\section{EXPERIMENTAL SETUP AND PROCEDURE}

The silver (Ag) nano-particles used in present experiments were $35 \mathrm{~nm}$ in size. The base working fluid was deionized (DI) water. Ag nano-fluids were prepared using a two-step method (Nanohubs technology Co., Ltd.). Ag nano-particles were prepared first. Ag nano-particles were produced using a catalytic chemical vapor deposition method. The Ag nanoparticles were then added to DI water. No surfactant was used in the Ag nano-fluid suspensions. The mixture was created using an ultrasonic homogenizer. Nano-fluid concentrations of $5 \mathrm{mg} / \mathrm{l}, 50 \mathrm{mg} / \mathrm{l}$ and $100 \mathrm{mg} / \mathrm{l}$ (ppm) were used in present study. An experimental system was set up to measure the wall temperature of FHP (Fig. 1). The thickness and length of the FHP used in these experiments were $3 \mathrm{~mm}$ and $200 \mathrm{~mm}$, respectively.

The wall temperature on the FHP was measured by four isolated type-T thermocouples. Two thermocouples were at-

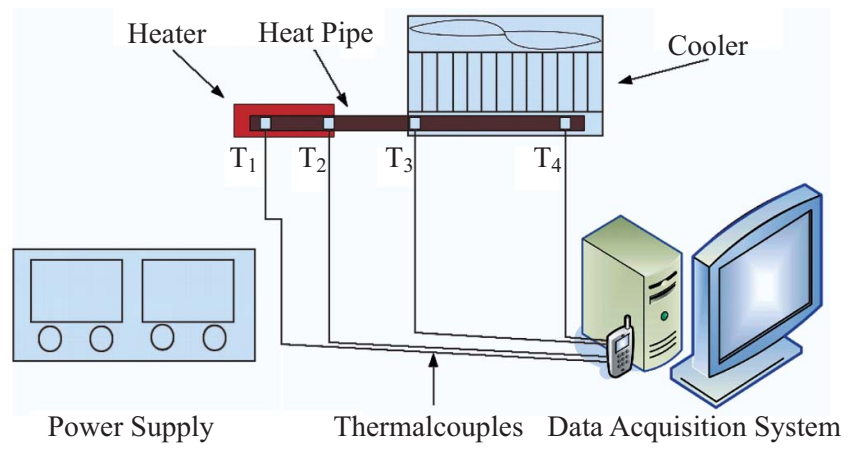

Fig. 1. Experimental setup and thermocouples distributions on the test FHP. 


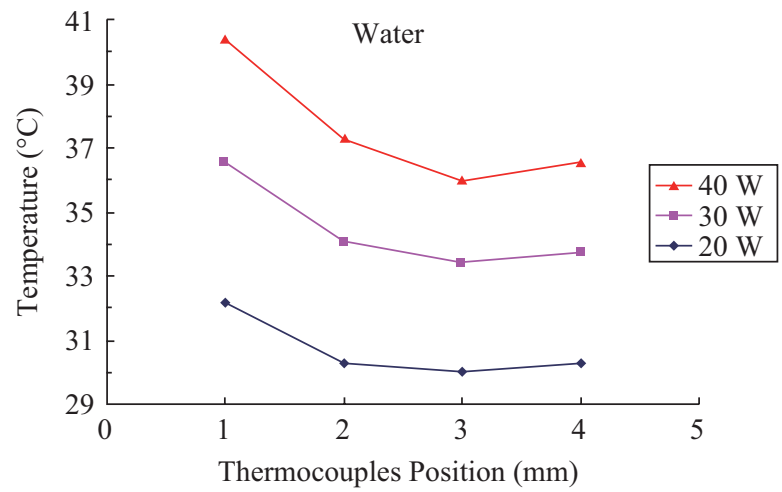

(a)

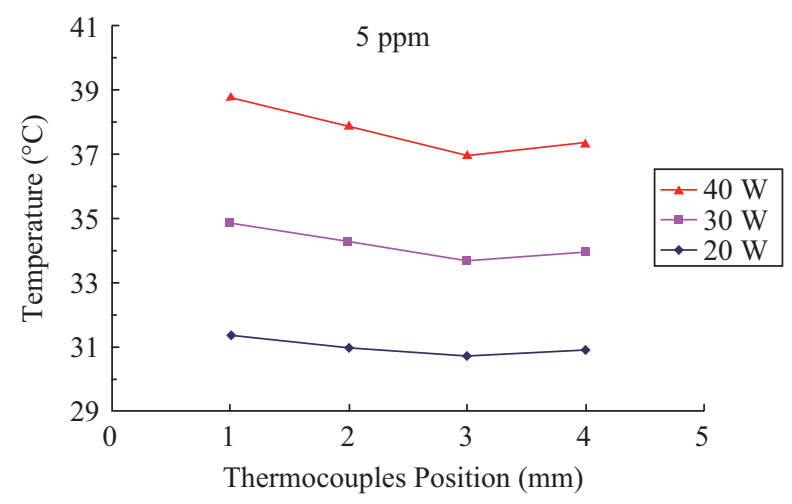

(b)

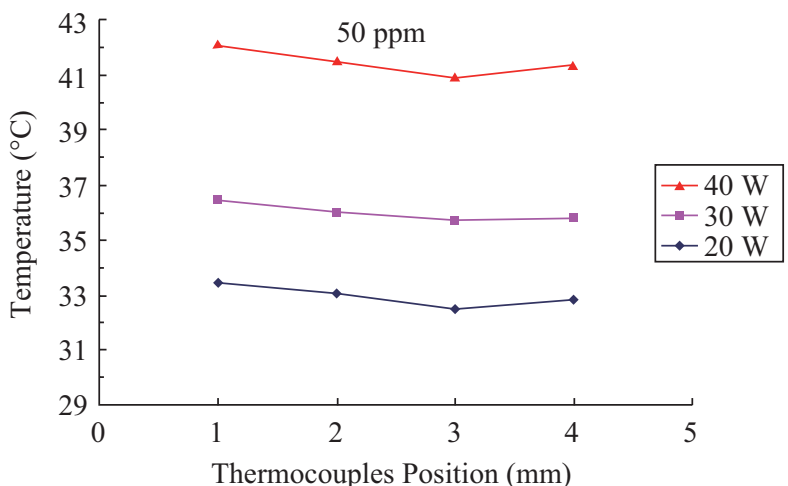

(c)

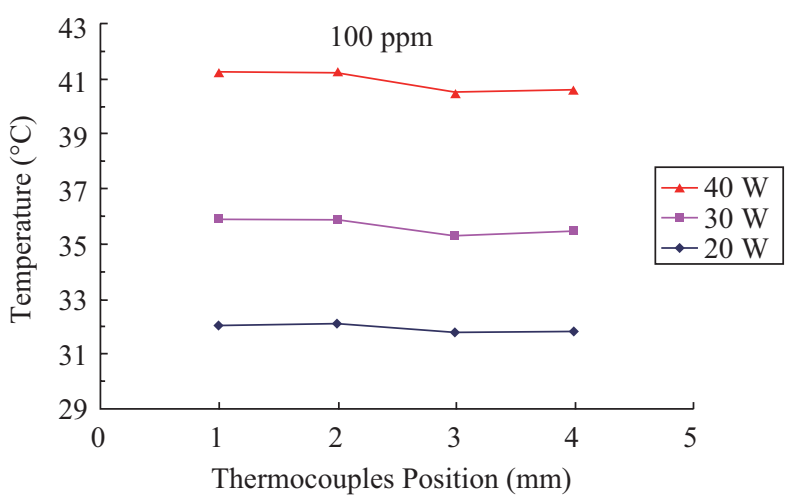

(d)

Fig. 2. Average temperature of FHP distribution in different input power and concentration.

tached to the evaporator; the others were attached to the condenser section. All thermocouples were calibrated against a quartz thermometer. The uncertainty in temperature measurements was $\pm 0.1^{\circ} \mathrm{C}$. The wall temperature is recorded by a data acquisition system (Testo 177-T4). Two heater bars (maximum $120 \mathrm{~W}$ ) were used as a heat source in the heating section and attached to the FHP evaporator using thermal grease (SHIN ETSU X-23-7762, $0.9 \mathrm{~W} / \mathrm{m}-\mathrm{K}$ ) over a length of $30 \mathrm{~mm}$ Thus, the heating load $(Q)$ and temperature difference $(d T=$ $\left.T_{\text {evaporator }}-T_{\text {condenser }}\right)$ were measured, and the thermal resistance $(R)$ of FHP was calculated by the equation, $R=d T / Q$. In the present study, the FHP was horizontally fixed during measurement.

The power supply was turned on and the power incremented. At this point in the tests, it took approximately 15 to 30 minutes to reach steady-state. Once the steady-state condition had been reached, the temperature distribution along the heat pipe was measured and recorded, along with the other experimental parameters. The power input was then increased incrementally, and the process repeated until dryout occurred as determined by rapid spikes in the evaporator thermal couple farthest from the condenser. Once dryout was reached, the temperature difference between the evaporator and condenser rapidly increased. The power input at this point was assumed to be the maximum heat transport capacity of the FHP.

\section{EXPERIMENTAL RESULTS}

Since the working fluid in the FHP that has a significant influence on its operation, thus present experiment will consider the various conditions of fluid to measure the temperature distribution of heat pipe and calculate the thermal resistance. Error bars based on the uncertainty in temperature measurements.

With the same filling ratio, the Fig. 2 showed the wall temperature distribution according to $200 \mathrm{~mm}$ FHP axial length with a thickness of $3 \mathrm{~mm}$ under the air-cooling. As Fig. 3 shown, the temperature difference of FHP containing pure water were $1.07^{\circ} \mathrm{C}, 1.72^{\circ} \mathrm{C}$ and $2.57^{\circ} \mathrm{C}$, respectively $(20 \mathrm{~W} \sim 40 \mathrm{~W})$. After adding small amount of $\mathrm{Ag}$ nanoparticles in the pure water illustrated a smaller temperature difference of FHP; $0.6^{\circ} \mathrm{C}, 0.79^{\circ} \mathrm{C}$ and $1.24^{\circ} \mathrm{C}(5 \mathrm{ppm}, 20 \mathrm{~W} 40 \mathrm{~W})$. The $50 \mathrm{ppm}$ nanofluid filled in the FHP, the temperature difference were $0.65^{\circ} \mathrm{C}, 0.52^{\circ} \mathrm{C}$ and $0.79^{\circ} \mathrm{C}(20 \mathrm{~W} \sim 40 \mathrm{~W})$, respectively. And the temperature difference of the $100 \mathrm{ppm}$ nanofluid FHP were $0.45^{\circ} \mathrm{C}, 0.51^{\circ} \mathrm{C}$ and $0.73^{\circ} \mathrm{C}(20 \mathrm{~W} \sim 40 \mathrm{~W})$, respectively. It also shows the more the nanopartilces were dispersed in working fluid, the smaller rise in temperature difference of FHP than pure was filled in heat pipe under various input power.

Figure 4 illustrates the influence of thermal resistance on FHP containing silver nanofluid and pure water as working 


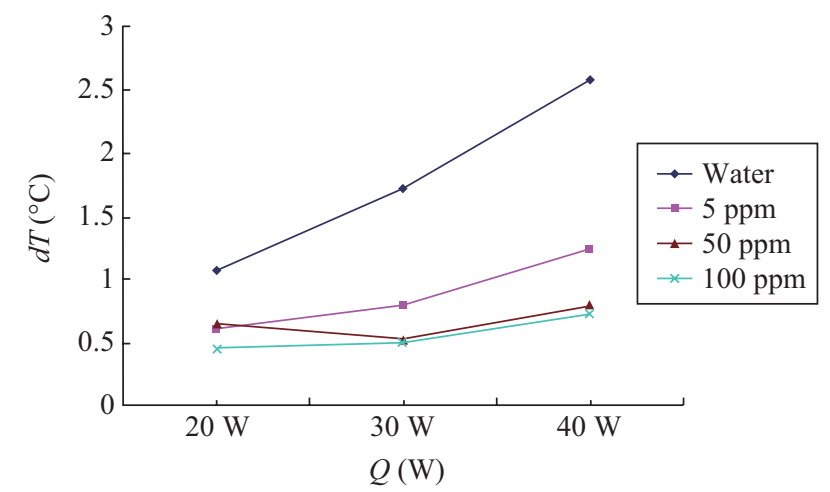

Fig. 3. Effect of particle concentration on the temperature difference of FHP under various input power.

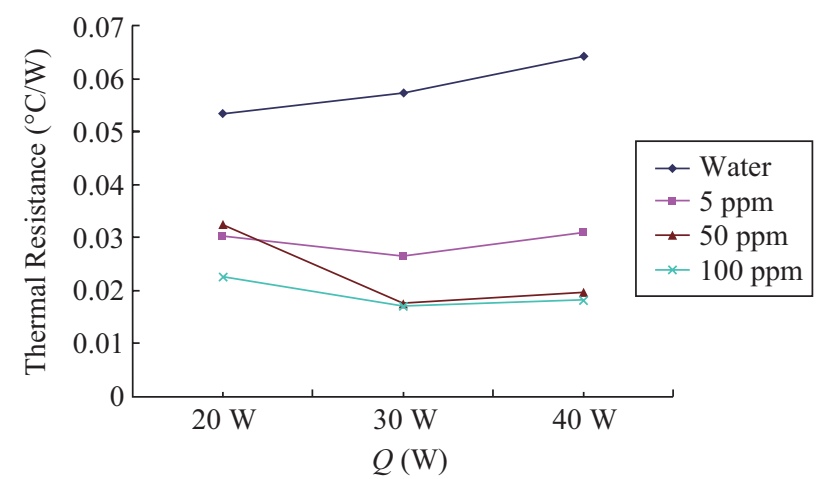

Fig. 4. Influence of particle concentration on the thermal resistance of FHP under various input power.

fluid. The result shows that thermal resistance of FHP filled pure water was higher than nano-fluid under $20 \mathrm{~W}$ to $40 \mathrm{~W}$. The effect of adding silver nanopartilces on the thermal performance of the FHP is more evident if the data are expressed as a plot of $R_{\text {water }}-R_{\text {nanofluid }} / R_{\text {water }}$ versus nanofluid concentration, as shown in Table 1. This table shows the range of reducing rate on thermal resistance were 0.39 to 0.71 under different concentration.

\section{SUMMARY}

The present study investigated the effect of flat heat pipe thermal performance using silver nano-fluid as the working fluid. The temperature difference and the thermal resistance of the FHP with silver nano-particle solution were lower than that with pure water.

Thermal conductivity and wettability of nanofluid are the advantages in heat pipe technology. The liquid-wick resistance of the heat pipe, included the effective thermal conductivity for the liquid-saturated wick structure, is one of major concern issue in overall thermal resistance evaluation [19]. However, the enhancement thermal performance of nano-fluid heat pipe do not strongly depend on the thermal conductivity of nanofluid [28].
Table 1. Reducing rate of thermal resistance.

\begin{tabular}{|c|c|c|c|}
\hline$R_{\text {water }}-R_{\text {nanofluid }} / R_{\text {water }}$ & $20 \mathrm{~W}$ & $30 \mathrm{~W}$ & $40 \mathrm{~W}$ \\
\hline $5 \mathrm{ppm}$ & 0.43 & 0.53 & 0.51 \\
\hline $50 \mathrm{ppm}$ & 0.39 & 0.69 & 0.69 \\
\hline $100 \mathrm{ppm}$ & 0.57 & 0.70 & 0.71 \\
\hline
\end{tabular}

Hence, the plausible reason for enhancing the thermal performance of FHP by using nano-fluid can be explained as: Because the nano-fluid is with higher wettability that can enhance the capability and flatten the temperature difference of FHP. Thus, the FHP could be enhanced the thermal performance by filling nano-fluid. This investigation showed that the silver nano-fluid not only enhanced the thermal performance of traditional circular heat pipes but also increased the flat heat pipe. In order to find the optimum its thermal performance, the further studies will focus on

(1) The effect between the thickness of FHP and nano-fluid concentration.

(2) The wettability effect of the nano-fluids on various geometry of the heat pipes wick.

\section{ACKNOWLEDGMENTS}

This work was supported by National Science Council of Taiwan, Republic of China under contract No. NSC 96-2622E-237-005-CC3. In addition, the author would like thank Professor Kang Shung-Wen (Department of Mechanical and Electro-Mechanical Engineering of Tamkang University, Taiwan) for his invaluable help and guidance.

\section{REFERENCES}

1. Chen, Y. T., Wei, W. C., Kang, S. W., and Yu, C. S., "Effect of nanofluid on flat heat pipe thermal performance," Semiconductor Thermal Measurement and Management Symposium, Semi-Therm Twenty-fourth Annual IEEE, 16-20 March, pp. 16-19 (2008).

2. Cho, T., Baek, I., Lee, J., and Park, S., "Preparation of nano-fluids containing suspended silver particles for enhancing fluid thermal conductivity of fluids," Journal of Industrial and Engineering Chemistry, Vol. 11, No. 3, pp. 400-406 (2005).

3. Choi, S. U. S., "Enhancing thermal conductivity of fluids with nanoparticles," ASME Fluids Engineering Division, Vol. 231, pp. 99-105 (1995).

4. Choi, S. U. S., Eastman, J. A., Li, S., Yu ,W., and Thompson, J., “Anomalously increased effective thermal conductivities of ethylene glycolbased containing copper nano-particles," Applied Physics Letters, Vol. 78, No. 6, pp. 718-720 (2001).

5. Choi, S. U. S., Wang, X., and Xu, W., "Thermal conductivity of nanoparticle-fluid mixture," Journal of Thermophysics and Heat Transfer, Vol 13, No. 4, pp. 474-480 (1999).

6. Das, S. K., Putra, N., Thiesen, P., and Roetzel, W., "Temperature dependence of thermal conductivity enhancement for nano-fluids," Journal of Heat Transfer, Vol. 125, pp. 567-574 (2003).

7. Daungthongsuk, W. and Wongwises, S., "A critical review of convective heat transfer of nanofluid," Renewable and Sustainable Energy Reviews, Vol. 11, pp. 797-817 (2007).

8. Kang, S. W., Wei, W. C., Tsai, S. H., and Huang, C. C., "Experimental 
investigation of nanofluids on sintered heat pipe thermal performance," Applied Thermal Engineering, Vol. 29, pp. 973-979 (2009).

9. Kang, S. W., Wei, W. C., Tsai, S. H., and Yang, S. Y., "Experimental investigation of silver nano-fluid on heat pipe thermal performance," Applied Thermal Engineering, Vol. 26, pp. 2377-2382 (2006).

10. Khandekar, S., Joshi, Y. M., and Mehta, B., "Thermal performance of closed two-phase thermosyphon using nanofluids," International Journal of Thermal Sciences, Vol. 47, pp. 659-667 (2008).

11. Lee, S., Choi, S. U. S., Eastman, J. A., and Lee, S., "Measuring thermal conductivity of fluids containing oxide nano-particles," ASME Journal of Heat Transfer, Vol. 121, pp. 280-289 (1999).

12. Li, C. H. and Peterson, G. P., "The effect of particle size on the effective thermal conductivity of $\mathrm{Al}_{2} \mathrm{O}_{3}$-water nanofluids," Journal of Applied Physics, Vol. 101, pp. 044312-1-044312-5 (2007).

13. Liu, Z. H., Xiong, J. G., and Bao, R., "Boiling heat transfer characteristics of nanofluids in a flat heat pipe evaporator with micro-grooved heating surface," International Journal of Multiphase Flow, Vol. 33, pp. 1284-1295 (2007).

14. Liu, Z. H., Yang, X. F., and Guo, G. L., "Effect of nanoparticles in nanofluids on thermal performance in a miniature thermosyphon," Journal of Applied Physics, Vol. 102, pp. 013526-1-013526-8 (2007).

15. Ma, H. B., Wilson, C., Borgmeyer, B., Park, K., Yu, Q., Choi, S. U. S., and Tirumala, M., "Effect of nanofluid on the heat transport capability in an oscillating heat pipe," Applied Physics Letters, Vol. 88, pp. 143116-1143116-3 (2006)

16. Ma, H. B., Wilson, C., Borgmeyer, B., Park, K., Yu, Q., Choi, S. U. S., and Tirumala, M., "An experimental investigation of heat transport capability in a nanofluid oscillating heat pipe," Journal of Heat Transfer, Vol. 128, pp. 1213-1216 (2006).

17. Park, K. and Ma, H. B., "Nanofluid effect on heat transport capability in a well-balanced oscillating heat pipe," Journal of Thermophysics and Heat Transfer, Vol. 21, No. 2, pp. 443-445 (2007).

18. Patel, H. E., Das, S. K., Sundararajan, T., Nair, A. S., George, B., and Pradeep, T., "Thermal conductivities of naked and monolayer protected metal nano-particles based nano-fluids: Manifestation of anomalous enhancement and chemical effects," Applied Physics Letters, Vol. 83, No. 14, pp. 2931-2933 (2003).

19. Peterson, G. P., An Introduction to Heat Pipes Modeling, Testing, and Applications, Wiley, New York (1994).

20. Shang, F.-M., Liu, D.-Y., Xian, H.-Z, Yang, Y.-P., and Du, X.-Z., "Heat transfer characteristics of $\mathrm{Cu}$-water in self-exciting mode oscillating-flow heat pipe," Dongli Gongcheng/Power Engineering, Vol. 27, No. 2, pp. 233236 (2007).

21. Shang, F.-M., Liu, D.-Y., Xian, H.-Z., Yang, Y.-P., and Du, X.-Z., "Flow and heat transfer characteristics of different forms of nanometer particles in oscillating heat pipe," Huagong Xuebao/Journal of Chemical Industry and Engineering (China), Vol. 58, No. 9, pp. 2200-2204 (2007).

22. Trisaksria, V. and Wongwises, S., "Critical review of heat transfer characteristics of nanofluids," Renewable and Sustainable Energy Reviews, Vol. 11, pp. 512-523 (2007).

23. Tsai, C. Y., Chien, H. T., Chan, B., Chen, P. H., Ding, P. P., and Luh, T. Y., "Effect of structural character of gold nano-particles in nanofluid on heat pipe thermal performance," Materials Letter, Vol. 58, pp. 1461-1465 (2004).

24. Wang, X. Q. and Mujumdar, A. S., "Heat transfer characteristics of nanofluids: A review," International Journal of Thermal Sciences, Vol. 46, pp. 1-19 (2007).

25. Wang, Y. and Peterson, G. P., "Investigation of a novel flat plate heat pipe," Journal of Heat Transfer, Vol. 127, pp. 165-170 (2005).

26. Wang, Y. and Vafai, K., "An experimental investigation of the thermal performance of an asymmetrical flat plate heat pipe," International Journal of Heat and Mass Transfer, Vol. 43, No. 15, pp. $2657-2668$ (2000).

27. Wang, Y. and Vafai, K., "An experimental investigation of the transient characteristics on a flat-plate heat pipe during startup and shutdown operations," Journal of Heat Transfer, Vol. 122, pp. 525-535 (2000).

28. Wei, W. C., Investigation of Silver Nano-fluid Heat Pipe Thermal Performance, Ph.D. Thesis, Department of Mechanical and Electro-Mechanical Engineering, Tamkang University, Taiwan (2008).

29. www.intel.com

30. Xie, X., Lee, H., Youn, W., and Choi, M., "Nano-fluids containing multiwalled carbon nano-tubes and their enhanced thermal conductivities," Journal of Applied Physics, Vol. 94, No. 8, pp. 4967-4971 (2003).

31. Xie, H., Wang, J., Xi, T., and Liu, Y., "Thermal conductivity of suspensions containing nano-sized SiC particles," International Journal of Thermophysics, Vol. 23, No. 2, pp. 571-580 (2002).

32. Xuan, Y. and Li, Q., "Heat transfer enhancement of nano-fluids," International Journal of Heat and Fluid Flow, Vol. 21, pp. 58-64 (2000).

33. Xuan, Y. and Li, Q., "Investigation on convective heat transfer and flow features of nano-fluids," Journal of Heat Transfer, Vol. 125, pp. 151-155 (2003).

34. Xue, H. S., Fan, J. R., Hu, Y. C., Hong, R. H., and Cen, K. F., "The interface effect of carbon nanotube suspension on the thermal performance of a two-phase closed thernosyphon," Journal of Applied Physics, Vol. 100, pp. 104909-1-104909-5 (2006).

35. Yang, X. F., Liu, Z. H., and Zhao, J., "Heat transfer performance of a horizontal micro-grooved heat pipe using $\mathrm{CuO}$ nanofluid," Journal of Micromechanics and Microengineering, Vol. 18, pp. 035038-1-035038-6 (2008). 